\title{
The Psychological Impact and suicidal behaviour in the context of COVID-19 pandemic, A Four Case report from Oman
}

Mandhar Al maqbali

Specialist in Psychiatrist, Ministry of health, Sohar, Oman

Salim Al-Huseini ( $\nabla$ salimalhuseini@gmail.com )

oman medical specialty baord https://orcid.org/0000-0002-6557-7033

Ahmad Mohamed Eltanahy

Anesthesia departments, Sohar hospital, Sultanate of Oman

Mohamed Elawdy

4Surgery departments, Sohar hospital, Sultanate of Oman

\section{Case Report}

Keywords: COVID, COVID-19, Corona virus, Suicide, Oman

Posted Date: July 26th, 2021

DOI: https://doi.org/10.21203/rs.3.rs-741841/v2

License: (c) (i) This work is licensed under a Creative Commons Attribution 4.0 International License.

Read Full License 


\section{Abstract}

Background: Mandatory quarantine during COVID-19 has disrupted normal social and economic life and many people became trapped and isolated with increasing levels of anxiety and financial difficulties. Especially for vulnerable people, COVID-19 pandemic had shown by many studies to increase the depressive and anxiety symptoms as well as suicidal ideation and suicidal attempts. Increased suicidal attempts had been associated with the increased burden of the health and economic impacts of the pandemic.

Cases Presentation: Here, we report four cases of suicidal attempts during the COVID 19 outbreak due to the lockdown and related economic difficulties. Those cases were admitted in a general hospital from the period April 2020 to June 2020.All patients were males, tested negative for corona virus and used violent methods of suicide. After receiving the appropriate treatment, all cases were discharged from hospital.

Conclusion: The COVID-19 pandemic and its economic and social impacts could result in significant consequences on vulnerable persons. As shown by many studies, Screening and early treatment are of paramount importance in preventing the mental health complications of the pandemic

\section{Background}

The negative impact of COVID-19 pandemic on public health is obvious with devastating morbidities and mortalities that were published in scientific journals. The negative impact of the pandemic has extended to include a variety of psychological and mental illnesses. Health quarantine, hospital admission in isolated units, personal equipment shields, and a daily negative news cycle- all predispose to depression and increase the risk of suicide in COVID patients that have reported recently ${ }^{1,2}$.Most governments enforced strict regulations and sanctions to limit the spread of the virus. This included: face masks, social distancing, societal lockdown, travel restrictions. On the other hand, these measures resulted in an increase the rate of unemployment, and threatened those working in small businesses and those who depend on a daily wage. All these factors affected the local and global economy with little cause for optimism ${ }^{3,4}$. Moreover, these factors not only compromise people who were affected by the virus, but also COVID negative cases at risk of suicide with few published case reports ${ }^{5,6}$. We investigated a series of four expatriate workers who attempted suicide due to persistent feelings of isolation, financial troubles and worries about their loved family members at home who were affected by COVID. All cases proved to be COVID negative, all were saved and treated and three were repatriated home at their requests. Based on the premise that the risk of suicide is not only evident during the pandemic itself, but also possibly in the months following its eradication ${ }^{7}$, we aimed to raise the awareness of health care providers of the negative psychological consequences of COVID. Moreover, to urge the relevant authorities at the national level to develop and implement a series of strategies that may help avoid such tragic events in the future. These can be achieved in collaboration with charity foundations to help in providing the financial aids to these vulnerable groups. All these combined measures could minimize the risk of suicide attempts. 


\section{Case Presentation}

Between April to July 2020, we received information on four expatriate workers who attempted suicide and were successfully treated. All were male, had no significant medical diseases and healthy with no known psychiatric illnesses. The medical history that were taken from their friends and roommates referred to them as normal individuals with no bizarre behaviors. Although they have different jobs and careers, all shared similar social and financial circumstances: the economic shutdown, lost jobs, lack of alternative income, and three of them had severely affected COVID-19 family members in their home countries. Routine blood investigations in all were normal, urine toxicology screening was also negative.

Physical examination showed the cut neck wounds in three and the hallmark of hanging in the fourth case. Patients with neck wounds were surgically treated, were admitted to the hospital for 10-14 days, and received psychotherapy. Three of them asked to travel to join their families, and after contacting their embassy, they were evacuated home, two in good general condition, and one with tracheoesophageal fistula. The other demographics, and data are in Table 1.

Table (1): Patients' demographics, methods of suicide, reasons for suicide, management and final disposal

\begin{tabular}{|c|c|c|c|c|c|c|}
\hline Case & $\begin{array}{l}\text { Personal, } \\
\text { social } \\
\text { history }\end{array}$ & $\begin{array}{l}\text { Reason for } \\
\text { attempting } \\
\text { suicide }\end{array}$ & $\begin{array}{l}\text { Method } \\
\text { of suicide }\end{array}$ & $\begin{array}{c}\text { Mini-mental state exam } \\
\text { (MMSE) }\end{array}$ & Management & Disposal \\
\hline $\begin{array}{l}\text { Case } \\
\text { (1) }\end{array}$ & $\begin{array}{c}\text { 26y, single, } \\
\text { engineer }\end{array}$ & $\begin{array}{l}\text { COVID } 19 \text { lock } \\
\text { down and border } \\
\text { closure }\end{array}$ & $\begin{array}{l}\text { Cutting } \\
\text { his throat } \\
\text { using a } \\
\text { razor }\end{array}$ & $\begin{array}{l}\text { Oriented x3 } \\
\text { Cooperative } \\
\text { Reactive affect }\end{array}$ & Psychotherapy & $\begin{array}{l}\text { transferred } \\
\text { to another } \\
\text { hospital by } \\
\text { means of } \\
\text { medical } \\
\text { evacuation }\end{array}$ \\
\hline $\begin{array}{l}\text { Case } \\
(2)\end{array}$ & $\begin{array}{l}\text { 24y, single, } \\
\text { driver }\end{array}$ & $\begin{array}{l}\text { Financial } \\
\text { problems related } \\
\text { to lock down of } \\
\text { COVID } 19\end{array}$ & $\begin{array}{l}\text { Cutting } \\
\text { his throat } \\
\text { using a } \\
\text { knife }\end{array}$ & $\begin{array}{l}\text { Cooperative } \\
\text { Good eye contact } \\
\text { No delusional thinking } \\
\text { or } \\
\text { perceptual changes }\end{array}$ & Psychotherapy & Discharged \\
\hline $\begin{array}{c}\text { Case } \\
\text { (3) }\end{array}$ & $\begin{array}{c}45 y, \\
\text { married, } \\
\text { restaurant } \\
\text { worker }\end{array}$ & $\begin{array}{lll}\text { COVID } & 19 & \text { lock } \\
\text { down } & & \end{array}$ & $\begin{array}{l}\text { Cutting } \\
\text { his throat } \\
\text { using a } \\
\text { knife }\end{array}$ & $\begin{array}{l}\text { Cooperative with } \\
\text { euthymic mood and no } \\
\text { delusional or perceptual } \\
\text { changes }\end{array}$ & Psychotherapy & $\begin{array}{l}\text { Evacuated } \\
\text { to home } \\
\text { country }\end{array}$ \\
\hline $\begin{array}{l}\text { Case } \\
(4)\end{array}$ & $\begin{array}{l}\text { 37y, single, } \\
\text { construction } \\
\text { worker }\end{array}$ & $\begin{array}{lll}\text { COVID } & 19 & \text { lock } \\
\text { down } & & \\
\end{array}$ & $\begin{array}{l}\text { Hanging } \\
\text { himself }\end{array}$ & $\begin{array}{l}\text { Cooperative with } \\
\text { euthymic mood and no } \\
\text { delusional or perceptual } \\
\text { changes }\end{array}$ & Psychotherapy & $\begin{array}{l}\text { Evacuated } \\
\text { to home } \\
\text { country }\end{array}$ \\
\hline
\end{tabular}

\section{Discussion}


As a consequence of COVID-19 societal lockdown, we introduced a case of four expatriate workers who felt isolated, had major financial troubles, and could not travel home to support their families who were sick with COVID. They attempted suicide, all were saved, and three were evacuated home.

COVID-19 is an airborne virus that affects mainly the respiratory system and is transmitted primarily by droplet infection and direct contact. In response to the rapid spread of the virus, most governments have responded rapidly with social distancing, isolation, staying home recommendations, and societal lockdown to minimize the spread of the infection. Additionally, most governments had to close most of the international borders and delay the issuing of visas. Certainly, these measures helped in minimizing the pressure on the health care system and limited the spread of the virus, and lowered the rate of mortalities that could be directly due to the virus. However, these sudden and repressive regulations are not free of negative consequences. They increased anxiety, stress, depression as well as the risk of suicide $^{4,8}$. The four cases in our series were typical examples who were negatively affected by the pandemic lockdown. They felt isolated and guilty as could not travel to help their loved family members who were sick with COVID-19 and also faced possible death. Social isolation contributes to the pathophysiology of psychiatric disorders and suicidal behavior. Also living alone gives rise to subjective feeling of depression which are strongly associated with suicide and that was reported in a large systematic review which included 40 articles $^{9}$.

The lockdown affected the whole structure of the economy and mostly affected more non-governmental sectors, small businesses and self-employed, and those drawing a daily wage. Despite the different jobs that were presented in our study, all had experienced major financial crises because of the lockdown and the subsequent effects on their daily income. The link between unemployment and financial troubles is known and was reported in many published articles ${ }^{10}$. Although Hempstead et al reported that hanging is the most common method of suicide due to financial troubles, only one subject in our series attempted suicide by hanging while the other three used knives ${ }^{11}$. This could be explained by the younger age range in our cases and this is in agreement with Hempstead et al who reported that the number of suicides using suffocation was $59.5 \%$ among those aged $40-64$ years compared with $18.0 \%$ for those aged $15-39$ years $^{11}$.

The data obtained from the deleterious effect of 2008 World global economic crisis is a good example to justify the reported cases of suicide in Oman and other countries. In a study that included 54 countries, Chang et al reported 4,884 excess suicide cases in 2009 compared with the number expected based on previous trends (2000-07) ${ }^{12}$. He concluded that after the 2008 economic crisis, rates of suicide increased in European and American countries respectively particularly in men and in countries with higher levels of job losses. Similarly, the four cases in our series were male and all lost their jobs.

The recent studies from different parts of the World on 2019 COVID pandemic showed similar findings. Initial reports from China by Wang et al evaluated 1,210 people from different cities in China and found that $16 \%$ had symptoms indicative of moderate to severe depression ${ }^{8}$. In subsequent studies in the US conducted by Google search, results that included the recent additions of words, phrases, and blogs that 
indicated depression and suicide, phrases such as: I lost my job, laid off, unemployment, help dramatically increasesd ${ }^{4}$. COVID-19 may have caused an increase in suicide risk factors that could yield long-term increase in suicidality and suicide rate ${ }^{4}$.

To date, a few case reports were published in the US, UK, Bangladesh, and India. Those cases presented findings based on the number of people who had committed suicide due to the combined factors of xenophobia, COVID-19, and negative media coverage. The reports illustrated the use of different terminology in relation to the chosen method of suicide: gunshot ${ }^{13}$, hanging ${ }^{5}$, knife $^{6}$. In our series, hanging was used in one case, and the others used knives. It must be noted that it is difficult to access guns in Oman. Alleviating stress, anxiety, feeling alone can be achieved by social media campaigns. Telephone calls, texts, and web chats can be used for this purpose even in cases of societal lockdown. RUOK (Are you OK) is a non-profit suicide preventive charity organization that was launched in Australia ${ }^{14}$. It aimed to access people affected by COVID-19 and provide help to those at-risk of suicide.

We hope that this research paper increases public awareness of the major and negative consequences of COVID-19 lockdown. This is crucial because it was reported that the risk of suicide is not only evident during the pandemic, but also, the rate may persist after its eradication ${ }^{7}$. The World Health Organization (WHO) announced that the pandemic may take a couple of years to control and the complete eradication of the virus will not be achieved without the development of an effective vaccine. The health care sector has to contact those patients and who are known to have psychiatric diseases who are at risk for suicide. Also, the government and the media have to encourage charity foundations to access those most badly affected and to provide help and support. All those strategic measures could minimize suicide.

\section{Conclusion}

Although governmental sanctions that included social isolation, societal lockdown, and international closure of borders have limited the spread of COVID-19, their psychological and financial deleterious effects have increased the risk of suicide. Expatriates, those who live and feel alone, and those who have had major financial troubles are at major risk. Preventive measures have to be taken by health care facilities, governments and charity foundations to avoid such tragic serious events.

\section{List Of Abbreviations}

COVID: COrona Virus Disease

\section{Declarations}

\section{Funding:}

This research did not receive any specific grant from funding agencies in the public, commercial, or nonprofit sectors" 


\section{Competing of interests:}

We declare no conflict of interest in preparing and writing this case report.

\section{Ethical approval and consent for publication:}

Ethical approval was obtained from Sohar Hospital administration office. All patients have written their informed consent. Administration office at Sohar hospital approved the study and permitted publication. The local policy for case reports does not require written consent from the participants and does not grant authors written and numbered ethical approval. The hospital polices recommends securing the identification data of all participants and monitors the adherence to the confidentiality policy of the hospital.

\section{Acknowledgment:}

We Acknowledge the Dr.Majid Almaqbali, Family Medicine Consultant, for his support and guidance in writing this paper.

\section{Authors' Contributions:}

MA and ME wrote the first draft, and literature review was conducted by SA and MT conducted the literature review. All authors contributed to the data collection, interpreting the results, and commenting on the initial manuscripts. All authors read and approved the final manusc

\section{References}

.1JR. M. British teen dies after suicide attempt due to coronavirus fears. New York Post, March 25, 2020.URL: https://nypost.com/2020/03/25/british-teen-dies-aftersuicide-attempt-due-to-coronavirusfears/.

.2Moore T BO. Man with cancer commits suicide at NYC hospital after getting coronavirus. https://nypostcom/2020/03/27/man-with-cancer-commits-suicide-at-nyc-hospital-aftergettingcoronavirus/. March 27, 2020. URL:.

.3Fitzpatrick KM, Harris C, Drawve G. How bad is it? Suicidality in the middle of the COVID-19 pandemic. Suicide \& life-threatening behavior. 2020.

.4Halford EA, Lake AM, Gould MS. Google searches for suicide and suicide risk factors in the early stages of the COVID-19 pandemic. PloS one. 2020;15(7):e0236777.

.5Goyal K, Chauhan P, Chhikara K, Gupta P, Singh MP. Fear of COVID 2019: First suicidal case in India ! Asian journal of psychiatry. 2020;49:101989. 
.6Mamun MA, Griffiths MD. First COVID-19 suicide case in Bangladesh due to fear of COVID-19 and xenophobia: Possible suicide prevention strategies. Asian journal of psychiatry. 2020;51:102073.

.7Sher L. Are COVID-19 survivors at increased risk for suicide? Acta neuropsychiatrica. 2020:1.

.8Wang C, Pan R, Wan X, et al. Immediate Psychological Responses and Associated Factors during the Initial Stage of the 2019 Coronavirus Disease (COVID-19) Epidemic among the General Population in China. International journal of environmental research and public health. 2020;17(5).

.9Calati R, Ferrari C, Brittner M, et al. Suicidal thoughts and behaviors and social isolation: A narrative review of the literature. Journal of affective disorders. 2019;245:653-667.

.10Pridmore S, Reddy A. Financial loss and suicide. The Malaysian journal of medical sciences : MJMS. 2012;19(2):74-76.

.11 Hempstead KA, Phillips JA. Rising suicide among adults aged 40-64 years: the role of job and financial circumstances. American journal of preventive medicine. 2015;48(5):491-500.

.12Chang SS, Stuckler D, Yip P, Gunnell D. Impact of 2008 global economic crisis on suicide: time trend study in 54 countries. BMJ (Clinical research ed). 2013;347:f5239.

.13K G. Illinois couple dead in murder-suicide after man feared they had coronavirus. URL: https://nypostcom/2020/04/07/illinoiscouple-dead-after-man-feared-they-had-covid-/19 .New York Post, April 7, 2020.

.14Are you OK? ;https://www.ruok.org.au/about-us. 